\title{
PENGARUH PENERAPAN PENDEKATAN KONTEKSTUAL TERHADAP PENINGKATAN KEMAMPUAN PEMECAHAN MASALAH MATEMATIS SISWA
}

\author{
Ratri Isharyadi \\ Universitas Pasir Pengaraian \\ E-mail: $\quad$ arya_math@ymail.com
}

\begin{abstract}
This study aims to examine the effect of applying the contextual approach to improving students' mathematical problem-solving competencies. Quasi-experimental research used with the design of nonequivalent control group. The population in this study were entire students of class VIII SMP Negeri 3 Lembang. The sampling technique used purposive sampling. Experimental learning class with the contextual approach and control class with the scientific approach. The instrument used is a problemsolving test. Data analysis was done using t-test. The results showed that the improvement of students' mathematical problem-solving skills in the experimental class was better than the students in the control class.
\end{abstract}

Keywords: Contextual Approach, Mathematical Problem Solving Competencies

\section{PENDAHULUAN}

Matematika merupakan alat penting bagi seseorang dalam menghadapi masalah dan tantangan dalam diri, pekerjaan, kehidupan sosial dan aspek ilmiah dalam kehidupan mereka. Dengan demikian, memiliki pemahaman matematika yang memadai sangat diperlukan untuk menerapkan matematika dalam memahami isu-isu penting dan memecahkan masalahmasalah yang bermakna (OECD,2013). Berdasarkan Permendiknas No. 22 tahun 2006 (BSNP, 2006) tentang Standar Isi Mata Pelajaran Matematika lingkup pendidikan dasar menyebutkan bahwa mata pelajaran matematika bertujuan agar peserta didik memiliki kemampuan sebagai berikut: (a) memahami konsep matematika, menjelaskan keterkaitan antar konsep dan mengaplikasikan konsep atau algoritma, secara luwes, akurat, efisien, dan tepat, dalam pemecahan masalah; (b) menggunakan penalaran pada pola dan sifat, melakukan manipulasi matematika dalam membuat generalisasi, menyusun bukti, atau menjelaskan gagasan dan pernyataan matematika; (c) memecahkan masalah yang meliputi kemampuan memahami masalah, merancang model matematika, menyelesaikan model dan menafsirkan solusi yang diperoleh; (d) mengkomunikasikan gagasan dengan simbol, tabel, diagram, atau media lain untuk memperjelas keadaan atau masalah; (e) memiliki sikap menghargai kegunaan matematika dalam kehidupan, yaitu memiliki rasa ingin tahu, perhatian, dan minat dalam mempelajari matematika, serta sikap ulet dan percaya diri dalam pemecahan masalah.

Bila dilihat dari tujuan mata pelajaran matematika setidaknya terdapat tiga butir yang menekankan pada kemampuan pemecahan masalah. Hal ini terlihat pada butir 1, 3 dan 5, meskipun secara keseluruhan tujuan pendidikan matematika berkaitan langsung dengan kemampuan pemecahan masalah. Kemampuan pemecahan masalah sendiri sudah menjadi standar yang harus dicapai pada pendidikan di Amerika Serikat bersama dengan kemampuan tingkat tinggi lainnya, yaitu penalaran dan 
pembuktian, komunikasi, koneksi dan representasi matematis (NCTM, 2000).

Sebagai kompetensi matematis, NCTM (2000) menyatakan bahwa indikator bagi siswa pra-TK sampai tingkat 12 dikatakan memiliki kemampuan pemecahan masalah apabila mampu: (1) Menerapkan dan beradaptasi dengan berbagai strategi yang tepat untuk memecahkan masalah; (b) Membangun pengetahuan matematika baru melalui pemecahan masalah; (c) Memecahkan masalah yang timbul dalam matematika dan dalam konteks lain; (d) Memantau dan merefleksikan proses pemecahan masalah matematika.

Sumarmo (2013) mengemukakan beberapa indikator kemampuan pemecahan masalah, yaitu: (1) mengidentifikasi kecukupan unsur untuk menyelesaikan masalah; (2) membuat model matematika dari suatu situasi atau masalah sehari-hari dan menyelesaikannya; (3) memilih dan menerapkan strategi yang tepat untuk menyelesaikan masalah matematika atau diluar matematika; (4) menjelaskan atau menginterpretasikan hasil sesuai permasalahan serta memeriksa kebenaran hasil atau jawaban; dan (5) menerapkan matematika bermakna.

Pentingnya kemampuan pemecahan masalah dinyatakan oleh NCTM (2000) bahwa melalui pemecahan masalah, siswa dapat mengalami kekuatan dan kegunaan matematika. Pemecahan masalah merupakan pusat penyelidikan dan aplikasi, sehingga harus terjalin dengan seluruh kurikulum matematika agar memberikan konteks untuk belajar dan menerapkan ide-ide matematika. Hal lain mengenai pentingnya kemampuan pemecahan masalah dinyatakan oleh NCSM (2007) yang meletakkan pemecahan masalah sebagai salah satu dari sepuluh basic skills yang harus dikuasai siswa, dengan menyatakan bahwa:

Learning to solve problems is the principal reason for studying mathematics. Problem solving is the process of applying previously acquired knowledge to new and unfamiliar situations. . . . In solving problems, students need to be able to apply the rules of logic necessary to arrive at valid conclusions. They must be able to determine which facts are relevant.

Conney (Widjajanti, 2009) juga menyatakan bahwa mengajarkan penyelesaian masalah kepada peserta didik, memungkinkan peserta didik tersebut menjadi lebih analitis dalam mengambil keputusan pada kehidupannya. Dengan kata lain, bila peserta didik dilatih menyelesaikan masalah, maka akan memudahkan peserta didik dalam mengambil keputusan, sebab peserta didik telah menjadi terampil dalam mengumpulkan informasi yang relevan, menganalisis informasi, dan menyadari betapa perlunya meneliti kembali hasil yang telah diperolehnya.

Pentingnya memiliki kemampuan pemecahan masalah seperti yang disajikan di atas, masih belum dapat dimaksimalkan, hal ini tentunya didasarkan pada penelitian-penelitian yang telah dilakukan yang masih menunjukkan bahwa kebanyakan siswa masih lemah dalam memecahkan masalah. Berdasarkan penelitian Marchis (2013), mengatakan bahwa dalam satu kelas tingkat dasar pada subjek penelitiannya, siswa dapat dengan mudah memecahkan masalah matematika rutin, tetapi hampir seperlima dari mereka membuat kesalahan perhitungan dalam penambahan atau pengurangan. 
Berkaitan dengan masalah non rutin, hanya separuh dari siswa memberikan jawaban yang benar, tetapi hanya seperempat dari siswa bisa memberikan argumentasi benar untuk jawaban mereka. Hasilnya menunjukkan perlunya meningkatkan jumlah masalah non-rutin dalam buku.

Sama halnya dengan penelitian yang dilakukan Marchis, pembelajaran di Indonesia masih banyak menggunakan masalah rutin, sehingga siswa akan kesulitan ketika dihadapkan dengan masalah nonrutin. Bila kita cermati buku-buku teks matematika untuk siswa yang digunakan di sekolahsekolah, termasuk bukubuku yang sudah lolos dari penilaian BSNP, maka tidak mudah untuk menemukan soalsoal latihan yang karakteristiknya seperti soal pemecahan masalah. Hal ini menyebabkan siswa kurang terlatih dalam memecahkan masalah yang tidak rutin yang membutuhkan penalaran dan kreativitas. Sugiman (2010) menyatakan bahwa sangat sedikit siswa SMP di Indonesia $(2.3 \%)$ yang mampu menyelesaikan soal yang kompleks yakni soal-soal pemecahan masalah yang memerlukan kemampuan berpikir tingkat tinggi. Hal lain yang berkaitan dengan kemampuan pemecahan masalah matematis juga terdapat pada hasil observasi yang dilakukan Murni (2012), yang menyatakan bahwa pelaksanaan pembelajaran pada beberapa kelas di beberapa SMP di kota Pekanbaru memperlihatkan bahwa siswa lebih dominan menyelesaikan soal rutin dari buku teks dan kurang memperoleh pengalaman menyelesaikan soal non rutin yang dapat melatih kemampuan pemecahan masalah. Menurutnya, kelemahan siswa terdapat pada menentukan model matematis, memilih strategi yang tepat dan sistematis, menggunakan konsep atau prinsip yang benar dan kesalahan komputasi.

Selanjutnya, berdasarkan studi pendahuluan yang peneliti lakukan di salah satu SMP di Bandung, meskipun sudah diterapkan kurikulum 2013, namun dari hasil tes kemampuan pemecahan masalah matematis, menunjukkan bahwa siswa belum memiliki kemampuan pemecahan masalah yang baik, siswa kesulitan dalam menginterpretasikan masalah, memilih strategi yang digunakan dalam memecahkan masalah matematika, dan mengubah soal ke dalam bahasa matematika (membuat model matematika). Hasil pengamatan di kelas, menunjukkan bahwa siswa kesulitan ketika diminta membuat model matematika, serta menyimpulkan suatu permasalahan. Berdasarkan faktafakta tersebut, kemampuan pemecahan masalah matematis siswa masih dalam kategori rendah, sehingga perlu diadakan usaha untuk meningkatkan kemampuan pemecahan masalah matematis.

Untuk mengatasi permasalahan di atas, maka dapat menerapkan pendekatan pembelajaran yang dapat meningkatkan kemampuan pemecahan masalah siswa. Salah satunya yaitu pendekatan pembelajaran kontekstual. Menurut Johnson (2006) pendekatan kontekstual merupakan suatu proses pendidikan yang bertujuan membantu siswa melihat makna dalam bahan pelajaran yang mereka pelajari dengan cara menghubungkannya dengan konteks kehidupan mereka sehari-hari, yaitu dengan konteks lingkungan pribadinya, sosialnya, dan budayanya. Dalam pendekatan kontekstual, guru menghadirkan situasi dunia nyata kedalam kelas dan mendorong siswa membuat hubungan antara pengetahuan yang dimilikinya dengan penerapannya dalam kehidupan mereka sebagai 
anggota keluarga dan masyarakat. Dengan konsep itu, hasil pembelajaran diharapkan lebih bermakna bagi siswa.

Untuk mencapai tujuan tersebut, pendekatan kontekstual akan menuntun siswa melalui tujuh komponen utama yaitu constructivism (siswa membangun pengetahuannya sendiri), inquiry (siswa dapat menemukan konsep), questioning (bertanya), learning community (masyarakat belajar), modeling (pemodelan), reflecting (refleksi) dan authentic assessment (penilaian autentik). Dengan menerapkan pendekatan pembelajaran kontekstual, yang melibatkan tujuh komponennya, diharapkan dapat meningkatkan kemampuan pemecahan masalah matematis siswa. Komponen constructivism dalam pendekatan kontekstual menurut Ulpah (2012) dapat memberikan kesempatan kepada siswa dalam menemukan dan menerapkan ide sendiri. Selain itu, komponen inquiry dan questioning juga membantu siswa dalam memahami dan merumuskan permasalahan matematika, karena pada proses pembelajaran siswa dapat menemukan konsep sendiri melalui bertanya, baik kepada guru maupun kepada siswa lainnya, sehingga diharapkan siswa dapat merumuskan masalah dengan baik.

Melalui learning community yang terdapat pada proses pembelajaran, siswa dapat mengambil keuntungan dengan saling berbagi dan berdiskusi dengan siswa lain, sehingga akan menambah wawasan dan ide siswa. Siswa juga dapat mengambil manfaat dengan adanya pemodelan, misalnya contoh penyelesaian masalah yang dilakukan oleh siswa lain maupun dari guru. Hal ini juga membantu siswa dalam melatih menerapkan strategi untuk menyelesaikan masalah. Berdasarkan uraian di atas, adapun tujuan penelitian ini yaitu untuk menelaah pengaruh penerapan pendekatan kontekstual dan besarnya pengaruh tersebut terhadap peningkatan kemampuan pemecahan masalah matematis siswa SMP.

\section{METODE PENELITIAN}

Penelitian ini dilaksanakan menggunakan metode penelitian kuasi eksperimen dengan pendekatan kuantitatif. Menurut Ruseffendi (2010) pada metode kuasi eksperimen, subjek tidak dikelompokkan secara acak, melainkan peneliti menerima keadaan subjek seadanya. Penelitian ini menggunakan desain "Nonequivalent Control-Group Design", Populasi pada penelitian ini adalah seluruh siswa kelas VIII di SMPN 3 Lembang, Provinsi Jawa Barat. Sampel penelitian ditentukan berdasarkan purposive sampling. Sebagai kelas Eksperimen adalah kelas $\mathrm{VIII}_{5}$ dan kelas Kontrol adalah kelas $\mathrm{VIII}_{3}$ dengan jumlah siswa pada masing-masing kelas adalah 40 . Instrumen untuk mengumpulkan data pada penelitian ini yaitu tes tertulis dalam bentuk essay (pre-test dan posttest). Pada penelitian ini soal tes terlebih dahulu diuji reliabilitas, validitas dan tingkat kesukaran. Analisis instrument menggunakan Rasch model, yang merupakan salah satu teori respon butir dengan bantuan program Winsteps. Hasil yang diperoleh adalah delapan butir soal yang digunakan valid dan reliabel, dengan koefisian reliabilitas tes adalah 0,76 dan koefisien reliabilitas item adalah 0,86. Maka realibilitas tes dan item termasuk ke dalam kategori bagus.

Analisis data menggunakan uji $\mathrm{t}$ dua sampel yang sebelumnya dilakukan uji prasyarat yaitu uji normalitas dan homogenitas. Data yang dianalis yaitu data $N$-Gain (peningkatan). Selanjutnya dilakukan perhitungan effect size. Effect size dihitung untuk mengetahui 
seberapa besar pengaruh pendekatan kontekstual terhadap peningkatan kemampuan pemecahan masalah matematis. Rumus yang digunakan adalah berdasarkan kriteria Gregory sebagai berikut.

$$
\widehat{\omega}^{2}=\frac{t^{2}-1}{t^{2}+n_{1}+n_{2}-1}
$$

Keterangan:

$\widehat{\omega}^{2}=$ Effect Size $\quad n_{2}=$ banyak sampel kelas kontrol

$t=$ nilai $\mathrm{t}$ hitung $\quad n_{1}=$ banyak sampel kelas eksperimen

\section{HASIL DAN PEMBAHASAN}

Hasil pre-test dan post-test kemampuan pemecahan masalah matematis diberi skor sesuai dengan pedoman penskoran yang telah ditetapkan oleh peneliti. Dari hasil pre- test dan post-test tersebut, digunakan untuk menentukan $n$-gain (peningkatan) kemampuan pemecahan masalah matematis siswa. Data n-gain digunakan untuk melihat apakah peningkatan kemampuan pemecahan masalah matematis siswa yang mendapat pembelajaran dengan pendekatan kontekstual lebih baik daripada siswa yang mendapatkan pembelajaran dengan pendekatan saintifik. $N$-gain dihitung dengan bantuan Micrososft Office Excel 2013 dengan cara membagi selisih data posttest dan data pre-test dengan selisih skor ideal dan data pre-test. Dari hasil analisis data pre-test, post-test dan $n$ gain, diperoleh deskripsi kemampuan pemecahan masalah yang disajikan dalam Tabel 1 berikut.

Tabel 1 Deskripsi Kemampuan Pemecahan Masalah Matematis

\begin{tabular}{|c|c|c|c|c|c|c|c|c|c|c|c|}
\hline \multirow{2}{*}{ Kelas } & \multirow{2}{*}{$\mathbf{N}$} & \multicolumn{3}{|c|}{ Pre-Test } & \multicolumn{3}{|c|}{ Post-Test } & \multicolumn{4}{|c|}{ N-Gain } \\
\hline & & Mean & $\%$ & SD & Mean & $\%$ & SD & Mean & $\%$ & SD & Kategori \\
\hline Kontekstual & 40 & 6,4 & 20 & 3,94 & 17,58 & 54,94 & 5,24 & 0,44 & 44 & 0,19 & Sedang \\
\hline Saintifik & 40 & 8,08 & 25,25 & 4,49 & 14,85 & 46,41 & 5,11 & 0,28 & 28 & 0,18 & Rendah \\
\hline
\end{tabular}

Berdasarkan Tabel 1, rerata skor pre-test, terlihat bahwa kelas yang akan diberikan pembelajaran saintifik memiliki nilai rerata 8,08 dan lebih tinggi dari rerata kelas yang akan diberikan pembelajaran kontekstual, yang hanya memiliki nilai rerata 6,40 . Selisih rerata antara kedua kelas adalah 1,68, yang apabila dikonversikan dalam bentuk persentase terhadap skor ideal, maka akan terlihat bahwa persentase pencapaian kelas saintifik adalah $25,25 \%$ atau $5,25 \%$ lebih tinggi daripada pencapaian kelas kontekstual yang hanya memperoleh $20 \%$. Perbedaan pencapaian antara kelas eksperimen dengan kelas kontrol masih tergolong rendah, sehingga kedua kelas memiliki kemampuan pemecahan masalah awal yang relative sama.

Pada bagian post-test, terlihat bahwa rerata kedua kelas berubah, dimana kelas kontekstual memiliki rerata 17,58, sedangkan kelas saintifik hanya memiliki rerata sebesar 14,85 . Artinya, selisih rerata antara kelas eksperimen dengan kelas kontrol adalah sebesar 2,73, yang apabila dikonversikan kedalam bentuk persentase, akan terlihat bahwa pencapaian persentase kelas eksperimen adalah $54,94 \%$ atau $8,53 \%$ lebih tinggi dibandingkan persentase pencapaian kelas kontrol, yaitu 46,41\%. Perbedaan rerata tersebut memperlihatkan bahwa 
rerata kelas kontekstual lebih baik daripada kelas saintifik.

Pada bagian n-gain, terlihat bahwa rerata $n$-gain kelas kontekstual adalah 0,44 , sedangkan rerata $n$-gain kelas saintifik adalah 0,28. Artinya kedua kelas memiliki perbedaan rerata n-gain sebesar 0,16. Bila dikonversikan kedalam bentuk persentase, maka rerata $n$-gain kelas kontekstual adalah 44\% atau lebih tinggi 16\% dibandingkan rerata n-gain kelas saintifik. Berdasarkan tabel tersebut, terlihat bahwa pencapaian n-gain kelas kontekstual lebih baik daripada pencapaian $n$-gain kelas saintifik, hal ini terlihat pada diagram berikut

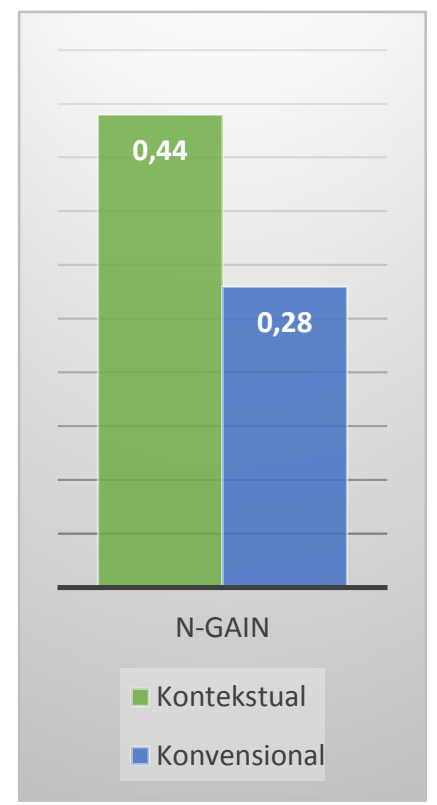

Gambar 1 Rerata Skor Pre-test dan Post-test

Kemampuan Pemecahan Masalah Matematis
Untuk mengetahui peningkatan kemampuan pemecahan masalah matematis antara siswa yang belajar melalui pendekatan kontekstual dengan siswa yang belajar melalui pendekatan saintifik, maka dilakukan analisis terhadap kelompok $\mathrm{N}$-gain antara siswa yang memperoleh kedua pembelajaran tersebut. Pertama dilakukan uji normalitas, diperoleh bahwa data $\mathrm{N}$ gain kemampuan pemecahan masalah matematis pada kedua kelompok berdistribusi normal, selanjutnya dilakukan uji homogenitas dan diperoleh kelas eksperimen dan kelas kontrol memiliki varians yang homogen. Dikarenakan data kedua kelompok berdistribusi normal dan homogeny maka dilanjutkan analisis data menggunakan uji t. Kriteria pengujian yang digunakan adalah jika nilai $p$-value (Sig.) lebih besar dari nilai $\alpha=0,05$, maka $\mathrm{H} 0$ diterima. Berikut hipotesis statistiknya:

$\mathrm{H}_{0}: \mu 1=\mu 2$

$\mathrm{H}_{1}: \mu 1>\mu 2$

Hipotesis yang diuji adalah:

$\mu 1$ : Rerata peningkatan kemampuan pemecahan masalah siswa yang mendapat pembelajaran dengan pendekatan kontekstual.

$\mu 2$ : Rerata peningkatan kemampuan pemecahan masalah siswa yang mendapat pembelajaran dengan pendekatan saintifik.

Perhitungan dilakukan dengan bantuan program SPSS 17, dengan hasilnya terlihat pada tabel berikut.

Tabel 2 Hasil Uji Perbedaan Rerata Skor $N$-Gain Kemampuan Pemecahan Masalah Matematis Siswa

\begin{tabular}{cccccccc}
\hline \multirow{2}{*}{ Hasil } & \multirow{2}{*}{ Kelas } & \multirow{2}{*}{ N } & Rerata & Standar & Sig. & Sig. & \multirow{2}{*}{ Kesimpulan } \\
\cline { 5 - 6 } \multirow{2}{*}{ N-Gain } & Eksperimen & 40 & 0,436 & 0,198 & \multirow{2}{*}{0,001} & 0,0005 & \multirow{2}{*}{ Tolak $\mathrm{H}_{0}$} \\
\cline { 2 - 5 } & Kontrol & 40 & 0,284 & 0,179 & (1-tailed) & \\
\hline
\end{tabular}


Berdasarkan Tabel 2, nilai signifikansi (1-tailed) yang diperoleh adalah 0,0005. Nilai signifikansi tersebut lebih rendah daripada taraf signifikansi $\quad \alpha=0,05, \quad$ sehingga kesimpulan yang diperoleh adalah tolak $H_{0}$. Artinya, peningkatan kemampuan pemecahan masalah matematis siswa yang memperoleh pembelajaran dengan pendekatan kontekstual lebih baik daripada siswa yang memperoleh pembelajaran dengan pendekatan saintifik.

Selanjutnya yang akan dilihat adalah seberapa besar pengaruh (effect size) yang diberikan pendekatan kontekstual dan pendekatan saintifik terhadap kemampuan pemecahan masalah matematis. Dari hasil perhitungan, untuk pendekatan kontekstual, diperoleh nilai $\widehat{\omega}^{2}=0,70$. Nilai tersebut menunjukkan bahwa pendekatan kontekstual memberikan pengaruh sebesar $70 \%$ terhadap kemampuan pemecahan masalah matematis. Untuk pendekatan saintifik, diperoleh nilai $\widehat{\omega}^{2}=0,53$, artinya pendekatan saintifik memberikan pengaruh terhadap kemampuan pemecahan masalah sebesar $53 \%$. Pengaruh yang diberikan pendekatan kontekstual lebih besar dibandingkan dengan pengaruh yang diberikan pendekatan saintifik. Selisih pengaruh antara kedua pendekatan tersebut adalah $17 \%$.

\section{KESIMPULAN DAN SARAN}

Berdasarkan hasil penelitian yang diperoleh setelah melakukan analisis dan pembahasan terhadap masalah yang telah dikemukakan dalam penelitian ini, dapat diambil kesimpulan bahwa peningkatan kemampuan pemecahan masalah matematis siswa yang mendapat pembelajaran dengan pendekatan kontekstual lebih baik daripada siswa yang mendapat pembelajaran dengan pendekatan saintifik. Dengan besar pengaruh yang diberikan pendekatan kontekstual adalah sebesar $70 \%$ lebih tinggi dibandingkan pengaruh yang diberikan pembelajaran saintifik yaitu $53 \%$. Adapun saran bagi peneliti yang ingin menerapkan pendekatan kontekstual, hendaknya memberikan porsi waktu yang lebih pada tahap diskusi kelas dan presentasi, karena pada tahap tersebut terjadi penyamaan persepsi yang membutuhkan banyak waktu. Peneliti selanjutnya dapat menelaah kemampuan pemecahan masalah menggunakan alternatif pembelajaran lainnya.

\section{DAFTAR PUSTAKA}

Badan Standar Nasional Pendidikan. 2006. Standar Isi untuk Satuan Pendidikan dasar dan Menengah. Jakarta: BSNP.

Johnson, E. B. 2006. Contextual Teaching and Learning: Menjadikan Kegiatan BelajarMengajar Mengasyikan Dan Bermakna. Mizan Learning Center.

Marchis, I. 2013. Future Primary and Preschool Pedagogy Specialization Students' Mathematical Problem Solving Competency. Acta Didactica Napocensia. Vol. 6, No. 2, Hal. $33-38$.

Murni, A. 2012. Peningkatan Kemampuan Pemecahan

Masalah Dan Representasi Matematis Siswa SMP Melalui Pembelajaran Metakognitif Berbasis Soft Skills. (Disertasi). Sekolah Pascasarjana, Universitas Pendidikan Indonesia, Bandung.

NCSM. 2007. Proving Student Achievement Through Designated District and School Mathematics Program Leaders. 
United States of America: The National Council of Supervisor of Mathematics, Inc.

NCTM. 2000. Principles Standards and For School Mathematics. United States of America: The National Council of Teachers of Mathematics, Inc.

OECD. 2013. PISA 2012 Assessment and Analytical Framework: Mathematics, Reading, Science, Problem Solving and Financial Literacy. OECD Publishing.

Ruseffendi, E. T. 2010. Dasar - Dasar Penelitian Pendidikan Dan Bidang Non Eksakta Lainnya. Bandung: Tarsito

Sugiman. 2010. Dampak Pembelajaran Matematika Realistik Terhadap Peningkatan Kemampuan Pemecahan Masalah Dan Keyakinan Matematik Siswa Sekolah Menengah Pertama Di Kota Yogyakarta. (Disertasi). Sekolah Pascasarjana, Universitas Pendidikan Indonesia, Bandung.

Sumarmo, U. 2013. Proses Berpikir Matematik: Apa dan Mengapa Dikembangkan. Berpikir dan Disposisi Matematik Serta Pembelajarannya. Bandung: Jurusan Pendidikan Matematika, Universitas Pendidikan Indonesia.

Sumintono, B \& Widhiarso, W. 2013. Aplikasi Model Rasch untuk Penelitian Ilmu-Ilmu Sosial. Bandung: Trim Komunikata Publishing House.

Ulpah, M. 2012. Peningkatan Kemampuan Penalaran Statistis Dan Self-Efficacy Siswa Madrasah Aliyah Melalui
Pembelajaran Kontekstual. Disertasi. Sekolah Pascasarjana, Universitas Pendidikan Indonesia, Bandung Widjajanti, D, B. 2009. Mengembangkan Keyakinan (Belief) Siswa Terhadap Matematika Melalui Pembelajaran Berbasis Masalah. Yogyakarta: UNY. 